\title{
High capacity optical links for datacentre connectivity
}

\author{
Tafur Monroy, Idelfonso ; Usuga, Mario; Vegas Olmos, Juan José
}

Link to article, DOI:

10.1109/ICTON.2015.7193564

Publication date:

2015

Document Version

Publisher's PDF, also known as Version of record

Link back to DTU Orbit

Citation (APA):

Tafur Monroy, I., Usuga, M., \& Vegas Olmos, J. J. (2015). High capacity optical links for datacentre connectivity. Abstract from 17th International Conference on Transparent Optical Networks, Budapest, Hungary. https://doi.org/10.1109/ICTON.2015.7193564

\section{General rights}

Copyright and moral rights for the publications made accessible in the public portal are retained by the authors and/or other copyright owners and it is a condition of accessing publications that users recognise and abide by the legal requirements associated with these rights.

- Users may download and print one copy of any publication from the public portal for the purpose of private study or research.

- You may not further distribute the material or use it for any profit-making activity or commercial gain

- You may freely distribute the URL identifying the publication in the public portal

If you believe that this document breaches copyright please contact us providing details, and we will remove access to the work immediately and investigate your claim 


\title{
High Capacity Optical Links for Datacentre Connectivity
}

I. Tafur Monroy ${ }^{1,2}$, Senior Member, IEEE, Mario Usuga ${ }^{1}$, and J. J. Vegas Olmos ${ }^{1}$, Senior Member, IEEE

${ }^{1}$ Technical University of Denmark, Department of Photonics Engineering, Ørsted Plads, Building 343, Kongens Lyngby, 2800, Denmark

${ }^{2}$ ITMO University, Visiting Professor, Saint Petersburg, Russia

e-mail:idtm@fotonik.dtu.dk

\begin{abstract}
There is a timely and growing demand for high capacity optical data transport solutions to provide connectivity inside data centres and between data centres located at different geographical locations. The requirements for reach are in the order of $2 \mathrm{~km}$ for intra-datacentre and up to $100 \mathrm{~km}$ for inter-datacentre connectivity. Moreover, the requirements for such connectivity solutions include also low cost, high data rate and desirable features such as energy efficiency and reduced interfacing cost. In this paper we review several approaches for intra and inter datacentre that use advanced modulation formats and multiplexing techniques to cope with the requirement of high capacity as well as techniques for reach extension.
\end{abstract}

Keywords: datacentre, short-range communications, connectivity, optical communications. 